\title{
Improving Civics Learning Outcomes Through Numbered Heads Together Class II Elementary School Learning Model
}

\author{
Ariska Yanuar Sari \\ SDIT Nur Rohman \\ ariskayanuarsari@gmail.com
}

\section{Article History}

received 3/12/2020

\begin{abstract}
The purpose of this research was to improve learning outcomes of Pancasila and Citizenship Education through the Numbered Head Together (NHT) model for Class II students of SDIT Nur Rohman. The research method is classroom action research with two cycles. The data analysis technique used is descriptive quantitative data analysis. Based on the improvement of the learning cycle I and cycle II, the learning outcomes of the first cycle can be presented which can achieve completeness as many as 20 students (80.00\%) with a class average of 81,2 . Cycle II learning outcomes that can achieve completeness are 25 students (100\%) with a class average of 86,9. Judging from the percentage of completeness and the average value of increasing learning outcomes, it can be concluded that the use of NHT type cooperative model in II class SDIT Nur Rohman Slogohimo can significantly improve learning outcomes.
\end{abstract}

Keywords: learning outcomes, numbered head together, Pancasila experience

\begin{abstract}
Abstrak
Tujuan penelitian ini adalah meningkatkan hasil belajar Pendidikan Pancasila dan Kewarganegaraan melalui model Numbered Head Together (NHT) pada Siswa Kelas II SDIT Nur Rohman. Metode penelitian yang digunakan adalah penelitian tindakan kelas dengan dua siklus. Teknik analisis data yang digunakan adalah analisis data deskriptif kuantitatif. Berdasarkan peningkatan pembelajaran siklus I dan siklus II, dapat disajikan hasil belajar siklus I yang dapat mencapai ketuntasan sebanyak 20 siswa $(80,00 \%)$ dengan rata-rata kelas 81,2 . Hasil belajar siklus II yang dapat mencapai ketuntasan adalah 25 siswa (100\%) dengan ratarata kelas 86,9 . Dilihat dari persentase ketuntasan dan nilai rata-rata peningkatan hasil belajar, dapat disimpulkan bahwa penggunaan model kooperatif tipe NHT di kelas II SDIT Nur Rohman Slogohimo dapat meningkatkan hasil belajar secara signifikan.
\end{abstract}

Kata kunci: hasil belajar, numbered head together, pengalaman Pancasila

Social, Humanities, and Education Studies (SHEs): Conference Series https://jurnal.uns.ac.id/shes

p-ISSN 2620-9284

e-ISSN 2620-9292 


\section{PENDAHULUAN}

Pendidikan Pancasila dan Kewarganegaraan (PPKn) adalah salah satu mata pelajaran wajib pada kurikulum pendidikan dasar dan menengah serta kurikulum pendidikan tinggi sebagaimana yang tertuang dalam Undang-Undang Nomor 20 Tahun 2003 tentang Sistem Pendidikan Nasional. Selain itu, Pasal 37 ayat (1) Kurikulum pendidikan dasar dan menengah wajib memuat: Pendidikan agama, Pendidikan kewarganegaraan, Bahasa, Matematika, IImu pengetahuan alam, IImu pengetahuan sosial, Seni dan budaya, Pendidikan jasmani dan olahraga, Ketrampilan/kejuruan, dan Muatan lokal dan ayat (2) Kurikulum pendidikan tinggi wajib memuat: Pendidikan agama, Pendidikan kewarganegaraan, dan Bahasa.

SDIT Nur Rohman adalah salah satu sekolah swasta di Kecamatan Slogohimo. Peserta didiknya berasal dari berbagai kecamatan. Kelas II adalah salah satu kelas yang heterogen dari segi akademik maupun jenis kelamin. Salah satu permasalahan yang ditemukan adalah 2 dari 25 siswa sering mengantuk ketika dijelaskan muatan pelajaran PPKn dan 8 di antaranya sering berbicara bahkan mengajak bermain teman di sebelahnya. Hasil penilaian harian muatan pelajaran PPKn materi Hubungan Antara Simbol dan Sila-Sila Pancasila dalam Lambang Negara yang diperoleh masih ada yang belum memenuhi KKM yaitu 16 anak dari 25 anak. Hanya 7 anak dari 25 yang selalu aktif berdiskusi dan mengerjakan tugas. Kurangnya skor hasil belajar juga disebabkan karena siswa belum lancar membaca. Mereka juga berasumsi bahwa PPKn merupakan pelajaran yang banyak mencatat sehingga melelahkan bagi anak yang belum mahir menulis dan konsepnya cenderung abstrak. Pembelajaran sudah menggunakan media gambar dan metode konvensional. Namun peserta didik belum mampu membedakan pengalaman pancasila antara satu dengan yang lain dan belum mampu mengaitkan pembelajaran dengan kehidupan sehari-hari.

Dari identifikasi masalah dapat diperoleh alternatif pemecahan masalah berupa perbaikan pembelajaran di kelas II SDIT Nur Rohman Slogohimo. Model pembelajaran kooperatif Numbered Heads Together dianggap cocok untuk kelas rendah khususnya kelas II pada muatan pelajaran PPKn materi Hubungan Antara Simbol dan Sila-Sila Pancasila dalam Lambang Negara karena mengajarkan siswa untuk belajar diskusi, mengemukakan pendapat yang dikemas secara menarik dengan penggunaan kepala bernomor. Selain dilatih bekerja sama untuk memecahkan masalah, peserta didik juga berlatih untuk membacakan hasil diskusinya kepada anggota kelas, sehingga menumbuhkan mental positif. Melalui metode Numbered Heads Together diharapkan siswa akan meningkat hasil belajarnya pada muatan pelajaran PPKn. Siswa dituntut untuk berperan aktif dalam kelompoknya sehingga tidak mudah merasa bosan dan tetap berkonsentrasi selama pembelajaran berlangsung.

Model pembelajaran menggambarkan keseluruhan aspek yang terjadi dalam pembelajaran dari awal pembelajaran, saat pembelajaran, maupun akhir pembelajaran tidak hanya pada guru namun juga siswa (Sundari, 2015:109), berdasarkan beberapa pernyataan para ahli, maka pemilihan model pembelajaran oleh guru harus tepat supaya tercapainya hasil belajar yang maksimal. Melalui memilih model pembelajaran yang tepat, proses pembelajaran lebih menyenangkan bagi siswa serta dapat meningkatkan kreativitas siswa. Dalam penelitian Kristian (2018:74) tentang pengaruh model pembelajaran Numbered Head Together (NHT) terhadap hasil belajar matematika beliau menyatakan pembelajaran kooperatif tipe Numbered Head Together merupakan salah satu model pembelajaran yang memberikan kesempatan kepada siswa untuk saling berbagi ide-ide dan mempertimbangkan jawaban yang paling tepat serta dirancang untuk mempengaruhi pola interaksi siswa dan sebagai alternatif terhadap struktur kelas tradisional. Numbered Head Together (NHT) adalah salah satu tipe pembelajaran kooperatif, model pembelajaran ini bertujuan untuk meningkatkan penguasaan akademik siswa dan meningkatkan interaksi antar siswa (Santiana, 2014:3). Sedangkan pengertian pembelajaran kooperatif dikemukakan Hamdayama 
(2016:132) Cooperative learning (pembelajaran kooperatif) merupakan salah satu model pembelajaran yang dapat membuat siswa aktif selama proses belajar dilakukan. Beliauvberpendapat bahwa model pembelajaran kooperatif dilakukan siswa dalam kelompok-kelompok kecil yang beranggotakan empat sampai enam orang siswa, kelompok-kelompok kecil ini dibentuk dengan tujuan dapat mencapai tujuan pembelajaran yang telah ditetapkan dengan cara siswa bekerjasama dengan siswa yang lain.

Menurut Huda (2013:203-204) terdapat lima langkah untuk melakukan model pembelajaran kooperatif tipe Numbered Head Together, yaitu : 1) siswa dibentuk dalam kelompok yang beranggotakan empat sampai enam orang, 2) setiap siswa yang sudah berada dalam kelompok diberi nomor, 3) masing-masing kelompok yang sudah dibentuk mendapatkan tugas atau pertanyaan dari guru, 4) setiap kelompok yang sudah diberi tugas atau pertanyaan oleh guru, maka anggota yang berada dalam kelompok tersebut bisa saling berdiskusi untuk menemukan jawaban yang paling tepat dan memastikan semua anggota kelompok mengetahui jawaban tersebut, 5) setelah berdiskusi dan mendapat jawaban yang menurut setiap kelompok benar, guru memanggil salah satu nomor secara acak dan siswa dengan nomor yang dipanggil dapat mempresentasikan jawaban dari kelompoknya. Adapun kelebihan dari model kooperatif tipe NHT adalah 1) mampu memperdalam pemahaman siswa, 2) melatih tanggung jawab siswa, 3) mengembangkan rasa ingin tahu siswa, 4) meningkatkan rasa percaya diri siswa, 5) menyenangkan siswa dalam belajar (Mahardika, 2018:3). Berdasarkan uraian di atas dapat ditarik kesimpulan yaitu proses pembelajaran membuat siswa merasa senang dan tidak bosan dikarenakan dapat berperan aktif dalam kelompoknya, dengan digunakannya model pembelajaran kooperatif tipe Numbered Head Together dalam kegiatan pembelajaran maka dapat mempengaruhi hasil belajar siswa.

Popi Radyuli (2019) menyatakan pendapat bahwa hasil belajar merupakan perubahan tingkah laku yang terjadi pada seseorang yang dapat diamati dan diukur dalam bentuk pengetahuan, sikap dan keterampilan. Ada beberapa faktor yang dapat mempengaruhi hasil belajar 1) faktor internal, merupakan faktor yang berasal dari diri sendiri, meliputi faktor fisiologis dan psikologi, 2) faktor eksternal, yaitu faktor yang berasal dari luar, meliputi faktor sosial dan non sosial (Suryabrata, 2010:235).

Rumusan masalah dalam penelitian ini adalah Bagaimanakah meningkatkan hasil belajar Pendidikan Pancasila dan Kewarganegaraan dengan model pembelajaran kooperatif tipe NHT pada Siswa Kelas II SDIT Nur Rohman? Sedangkan untuk tujuan penelitian yaitu meningkatkan hasil belajar Pendidikan Pancasila dan Kewarganegaraan melalui model Numbered Head Together (NHT) pada Siswa Kelas II SDIT Nur Rohman.

\section{METODE}

Metode penelitian yang digunakan yaitu penelitian tindakan kelas. Penelitian dilaksanakan di SDIT Nur Rohman Desa Waru Kecamatan Slogohimo Kabupaten Wonogiri pada bulan Maret sampai Juni 2020 sebanyak 2 siklus, siklus I tanggal 14 April 2020 dan siklus 2 pada tanggal 4 Mei 2020. Subyek penelitian dalam penelitian ini adalah siswa kelas II SDIT Nur Rohman, berjumlah 25 siswa terdiri dari 15 laki-laki dan 10 perempuan dengan kemampuan heterogen. Obyek penelitian berupa penerapan pembelajaran kooperatif tipe Numbered Heads Together dalam meningkatkan hasil belajar siswa terhadap mata pelajaran Pendidikan Kewarganegaraan. Pada setiap akhir siklus data yang dikumpulkan dalam penelitian ini adalah data kuantitatif yaitu tes sumatif. Analisis penelitian ini adalah analisis deskriptif kuantitatif kualitatif, artinya selain menyajikan hasil berupa angka, tetapi peneliti juga menuliskan analisis berupa kalimat. Penelitian ini menggunakan teknik triangulasi penyelidikan dengan jalan memanfaatkan penelitian dan penguatan untuk keperluan pengecekan kembali derajat 
kepercayaan data. Pemantapan lainnya adalah guru sebagi peneliti, kepala sekolah serta teman sejawat dapat membantu mengurangi kemencengan dalam pengumpulan data. Data dalam penelitian dapat dikumpulkan melalui beberapa metode, antara lain: Tes, Angket atau questioner, Observasi, dan Dokumentasi.

\section{HASIL DAN PEMBAHASAN}

Dari hasil observasi sebelum diterapkan model pembelajaran kooperatif tipe Numbered Heads Together, diperoleh pada tahap pra siklus dapat diketahui bahwa dari 25 anak yang sudah tuntas ada 5 anak. Nilai tertinggi pada mata pelajaran PPKn yaitu 90 sedangkan nilai terendah yaitu 40 . Rata-rata kelas untuk mata pelajaran PPKn adalah 65,2 sehingga ketuntasan klasikal diperoleh $20 \%$. Pelaksanaan tindakan pada siklus I, guru menginformasikan kepada siswa model pembelajaran yang akan digunakan yaitu model pembelajaran tipe Numbered Heads Together. Kemudian membagi siswa dalam kelompok yang terdiri antara 4-5 anggota tiap kelompok, kemudian kepada setiap kelompok diberi nomor 1-4. Pada kegiatan inti guru menyajikan materi tentang hubungan antara symbol dan sila ke-1 pancasila. Kemudian guru menyuruh siswa bergabung dengan kelompoknya masing-masing. Setelah berada dalam kelompoknya guru membagikan lembar kerja siswa, dan meminta siswa menyelesaikan soal-soal dalam lembar kerja siswa. Selama siswa menyelesaikan soal dalam lembar kerja siswa guru memantau kerja tiap-tiap kelompok. Guru selalu mengingatkan agar dalam kerja kelompok dikerjakan bersama, sehingga tiap-tiap anggota memahami jawaban yang dimaksud. Setelah semua siswa selesai menyelesaikan soal yang diberikan, guru secara acak memanggil anggota siswa dalam kelompok untuk menjawab atau mempresentasikan hasil kerja kelompoknya. Sedangkan kelompok yang lain menanggapi, akan tetapi selama presentasi tidak ada siswa yang menanggapi. Kemudian guru menyimpulkan jawaban siswa.Berdasarkan hasil belajar siswa diperoleh pada siklus I, dapat diketahui bahwa dari 25 anak yang belum tuntas ada 5 anak. Nilai tertinggi pada mata pelajaran PPKn yaitu 90 sedangkan nilai terendah yaitu 50. Rata-rata kelas untuk mata pelajaran PPKn adalah 81,2 sehingga ketuntasan klasikalnya $80 \%$. Penerapan pembelajaran diorientasikan pada kerja kelompok pada siklus I belum dapat dilaksanakan secara optimal, sebab siswa masih nampak belajar secara individu dan tergantung pada instruksi guru. Hal ini teijadi karena siswa belum terbiasa menggunakan metode Numbered Heads Together sehingga siswa masih menyesuaikan diri.

Pada tindakan siklus II, guru mengadakan penyempumaan pada perangkat pembelajaran yang terdiri dari silabus, rencana pelaksanaan pembelajaran, media dan alat evaluasi. Untuk kegiatan pembelajaran guru mempersiapkan lembar kerja siswa serta lembar pengamatan. Perencanaan dibuat berdasarkan hasil refleksi siklus 1. Berdasarkan hasil pengamatan pada tindakan siklus II, kegiatan guru dalam melaksanakan proses pembelajaran telah meningkat. Dimana kekurangan-kekurangan pada siklus I sudah dapat diperbaiki. Siswa lebih antusias dalam mengikuti pembelajaran, terlihat ada sebagian siswa yang berani menanyakan kepada guru tentang materi yang belum jelas, mengeluarkan pendapat dan menanggapi presentasi dari kelompok lain. Nilai siswa pada tindakan siklus II ada peningkatan, dimana semua siswa tidak ada yang mendapat nilai di bawah 76 . Peningkatan rata-rata hasil belajar adalah $3.95 \%$. Nilai tertinggi pada mata pelajaran PPKn yaitu 100 sedangkan nilai terendah yaitu 80. Rata-rata kelas untuk mata pelajaran PPKn adalah 86,875. Ketuntasan klasikal diperoleh $100 \%$, sehingga berdasarkan refleksi, maka siklus III dihentikan. Perbandingan hasil belajar siswa pada tahap pra siklus, siklus I dan siklus II dapat dilihat pada tabel berikut: 
Tabel 1. Hasil Belajar Siswa Tahap Pra Siklus, Siklus I, dan Siklus II

\begin{tabular}{cccc}
\hline Nilai & Pra Siklus & Siklus I & Siklus II \\
\hline Nilai Tertinggi & 90 & 90 & 100 \\
Nilai Terendah & 40 & 70 & 80 \\
Jumlah & 1630 & 2030 & 2200 \\
Rata-rata & 65,2 & 81.2 & 86.87 \\
\hline
\end{tabular}

Berdasarkan tabel di atas dapat dianalisis bahwa peningkatan hasil belajar Pendidikan Kewarganegaraan siswa setelah diterapkan metode pembelajaran kooperatif tipe Numbered Heads Together, karena metode ini memberi kesempatan kepada siswa dapat lebih meningkatkan terhadap pemahaman konsep; dengan jalan saling berkomunikasi dengan temannya sendiri lewat diskusi. Jadi tugas guru dalam pembelajaran kooperatif tipe Numbered Heads Together sebagai fasilitator dalam proses pembelajaran, selain itu memberikan arahan dan bimbingan agar pembelajaran berlangsung dengan baik. Sedangkan untuk aktivitas belajar siswa dapat diamati pada gambar berikut:

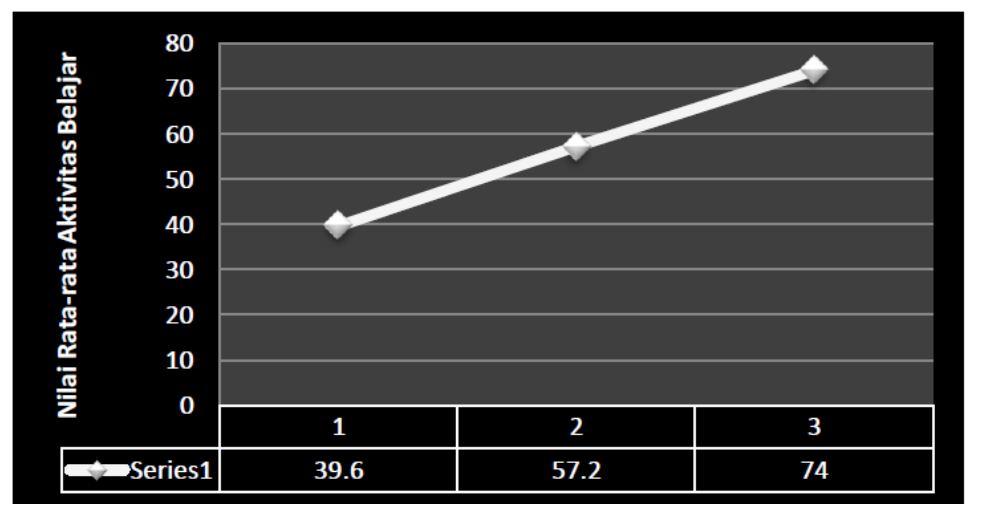

Gambar 1. Aktivitas Belajar Siswa dari Pra Siklus, Siklus I dan siklus II

Aktivitas belajar yang diamati dalam lembar observasi antara lain: membaca, bertanya, menjawab pertanyaan, mengerjakan tugas kelompok, mencatat, kerjasama, keaktifan, dan menanggapi. Dari gambar 1 menunjukkan aktivitas belajar siswa pada tahap pra siklus sebesar 39,6 dan pada ajkir siklus mencapai 74. Hal ini disebabkan karena disamping meningkatkan hasil belajar, model Numbered Head Together juga meningkatkan motivasi belajar siswa.

Penelitian lain tentang model NHT dapat mempengaruhi hasil belajar, salah satunya dilakukan oleh Desy Nilam Sari, Suyitno Suyitno, (2018) yang berjudul "Keefektifan Model Number Head Toghether Terhadap Hasil Belajar IPS Kelas III SD Negeri Danyangmulyo 02 Kabupaten Pati" mendapatkan hasil penelitian bahwa model pembelajaran kooperatif tipe Numbered Head Together berpengaruh untuk meningkatkan hasil belajar siswa Sekolah Dasar. Senada dengan itu, penelitian yang dilakukan Tantri (2018) mendapat hasil bahwa hasil belajar siswa pada model pembelajaran TGT \& NHT lebih baik dibandingkan dengan hasil belajar pada model pembelajaran langsung. Selain itu, penelitian yang dilakukan oleh I Md. Oka Susila, I Wyn. Rinda Suardika, (2015) dengan judul "Model Pembelajaran Kooperatif Tipe NHT Berbantuan Media Konkret Berpengaruh Terhadap Hasil Belajar Matematika Siswa Kelas V SD Gugus VII Kecamatan Gianyar" membuktikan bahwa terdapat perbedaan signifikan terhadap hasil belajar matematika ketika siswa belajar menggunakan model pembelajaran kooperatif tipe Numbered Head Together dengan siswa belajar menggunakan model pembelajaran konvensional, jadi dapat disimpulkan model pembelajaran kooperatif tipe Numbered Head Together berpengaruh pada hasil belajar siswa Sekolah Dasar. 


\section{SIMPULAN}

Melalui pembelajaran kooperatif tipe Numbered Heads Together pada pembelajaran Pendidikan Kewarganegaraan materi "Hubungan symbol dan Sila-Sila Pancasila Dalam Lambang Negara" terbukti dapat meningkatkan hasil belajar Pendidikan Kewarganegaraan peserta didik kelas II di SDIT Nur Rohman Slogohimo. $\mathrm{Hal}$ ini dapat dilihat dari peningkatan rata-rata nilai hasil belajar mulai pra siklus, siklus 1 dan siklus 2 yaitu: 65.2 ; 81.2 ; 86.9. Sedangkan aktivitas belajar siswa dari pra siklus, siklus 1 dan siklus 2 yaitu: 39.6 ; 57.2; 74. Model pembelajaran NHT direkomendasikan untuk peserta didik kelas rendah karena mereka masih menyukai hal-hal konkret dan bersifat menarik. Selain itu sistem belajar lebih bermakna dengan menghadirkan pengalaman langsung dalam kehidupan sehari-hari. Bagi guru, hasil penelitian ini dapat digunakan sebagai pertimbangan dalam perencanaan dan pelaksanaan pembelajaran tematik atau mata pelajaran lain yang disesuaikan dengan materinya. Bagi institusi hasill penelitian ini secara praktis dapat digunakan sebagai pertimbangan institusi untuk meningkatkan hasil belajar peserta didik dalam rangka pencapaian ketuntasan kriteria ketuntasan minimal (KKM) pada satuan tingkat pendidikan.

\section{DAFTAR PUSTAKA}

Desy Nilam Sari, Suyitno Suyitno, I. L. (2018). Keefektifan Model Number Head Together Terhadap Hasil Belajar IPS Kelas III SD Negeri Danyangmulyo 02 Kabupaten Pati. Prosiding Seminar Nasional Hima dan Prodi PGSD 2017.

Hamdayama, J. (2016). Metodologi pengajaran. Jakarta: Bumi Aksara.

Huda, M. (2013). Model-model Pengajaran dan Pembelajaran. Yogyakarta: Pustaka Pelajar.

I Md. Oka Susila, I Wyn. Rinda Suardika, I. W. S. Uniasih. (2015). Model Pembelajaran Kooperatif Tipe NHT Berbantuan Media Konkret Berpengaruh Terhadap Hasil Belajar Matematika Siswa Kelas V SD Gugus VII Kecamatan Gianyar. E-Journal PGSD Universitas Pendidikan Ganesha, 3(1).

Kementrian Pendidikan dan Kebudayaan RI. (2003). Undang-undang Republik Indonesia No. 20 Tahun 2003 tentang Sisdiknas. Jakarta : Lembaran Negara Republik Indonesia.

Kristian, A. (2018). Pengaruh Model Pembelajaran Numbered Head Together (NHT) Terhadap Hasil Belajar Matematika Siswa di Kelas IV SDN 4 Banda Aceh. Genta Mulia: Jurnal IImiah Pendidikan, IX(2), 71-82.

Mahardika, I. P. M., Dantes, N., \& Widiana, W. (2018). Pengaruh Model Pembelajaran Numbered Heads Together Terhadap Hasil Belajar IPS Pada Siswa Kelas V SD Gugus V Kintamani Tahun Pelajaran 2017/2018. Mimbar PGSD Undiksha, 6(1), 1-32. Diakses dari: https://ejournal.undiksha.ac.id

Popi Radyuli, Rini Sefriani, Nurul Qomariah. (2019). Pembelajaran Inquiry Menggunakan Google Form Terhadap Hasil Belajar Simulasi dan Komunikasi Digital. Edukatif Jurnal Ilmu Pendidikan, 1(2), 56-96.

Santiana, N. L. P. M., Sudana, D. N., \& Garminah, N. N. (2014). Pengaruh Model Pembelajaran Kooperatif Tipe Numbered Heads Together (NHT) Terhadap Hasil Belajar Matematika Siswa Kelas V Sekolah Dasar di Desa Alasangker. Mimbar PGSD Undiksha.

Sardiman, A. M. (2007). Interaksi dan Motivasi Belajar Mengajar. Jakarta: PT Raja Grafindo Persada.

Sundari, H. (2015). Model-Model Pembelajaran dan Pemerolehan Bahasa Kedua/Asing. Jurnal Pujangga, 106-117.

Suryabrata, S. (2010). Psikologi Pendidikan. Raja Grafindo Persada. 
Tantri, P. Y. A. (2018). Pengaruh Model Pembelajaran Teams Games Tournament Dan Numbered-Heads Together Terhadap Hasil Belajar IPA Ditinjau Dari Motivasi Belajar siswa Kelas IV Sekolah Dasar. Tesis. Diakses dari: http://library.uns.ac.id 